\title{
Analysis of Contemporary College Students' Sense of Social Responsibility and Its Cultivation
}

\author{
Yanmin $\mathrm{Yu}$ \\ Jilin Engineering Normal University, Changchun, Jilin, 130052
}

Keywords: Contemporary college students; Sense of social responsibility; Importance; Reason; Path

\begin{abstract}
With the continuous development of knowledge economy, knowledge as the primary productive force has received extensive attention from all walks of life. The contemporary college students, as the carrier of professional theoretical knowledge, are the mainstay of the future development of society, affecting the future development of our country. Meanwhile, the contemporary college students are also the important part of the future society. Their thoughts, words and deeds will have a direct and far-reaching impact on society. For college students, the sense of social responsibility, on the one hand, is related to their own growth, on the other hand is related to the rise and fall of the social development. This paper starts from the importance of cultivating college students' sense of social responsibility, analyzes the lack of sense of social responsibility of contemporary college students in detail and puts forward the important path to cultivate the sense of social responsibility of contemporary college students for discussion and reference.
\end{abstract}

\section{Introduction}

The Party and the country will both take the realization of the great rejuvenation of the Chinese nation as the sacred mission of this generation of Chinese people. The experience of historical development tells us that the younger generation plays a decisive role in the mission of national rejuvenation, especially their sense of social responsibility. As an important component of the national youth, the contemporary college students in our country are the bearers of national rejuvenation. Therefore, the sense of social responsibility of contemporary college students is an important issue worthy of great attention.

\section{The Concept and Importance of the Sense of Social Responsibility}

Concept. From the perspective of psychology, the sense of social responsibility is the individual psychological quality that the individual actively fulfills the responsibility and obligation of social morality. From the perspective of ideological and political education, the sense of social responsibility is the self-awareness of individuals that they should fulfill various obligations and undertake the social responsibility and it is also a kind of consciousness of social responsibility. From the perspective of the ethics, the sense of social responsibility is an ethical concern and obligation of individuals in their hearts and feelings towards others in a particular society.

The Importance of Cultivating the Sense of Social Responsibility of Contemporary College Students. The first one is that the realistic society urgently demands to strengthen the education of the sense of social responsibility of college students. In recent years, with the continuous development of the network news level, the moral deficiency of many college students has been repeatedly exposed, causing the society to worry about it. The events that many college students lack moral repeatedly occur, for example, the beautiful college student abused the rabbit, college student splashed the sulphuric acid to the bear, etc. These events reflect the current situation of the lack of the sense of social responsibility of contemporary college students. Contemporary college students are the future of the motherland, are also the important force for the future development of the motherland. Therefore, the sense of social responsibility of this generation will have an indelible impact on the social atmosphere and development. 
The second one is that the growth and success of contemporary college students can't be separated from the education of sense of social responsibility. As a member of the motherland, we have a certain responsibility for whatever ourselves, others, collectives or our country. For college students, the sense of social responsibility is an important factor of their healthy growth, and meanwhile it is also the important embodiment of the healthy personality. College period is the preparatory period for the college student to enter the society. Although they have formed a relatively complete worldview and values, there are still many deficiencies in the self constraint of their ideas, they lack the reasonable grasp for themselves, their future and the path of life. Modern college students are the important forces for the future social construction, and the future of the motherland depends on the efforts of this generation. Therefore, as a new generation of college students, they should have the consciousness to undertake the responsibility and fulfill the obligation. For the current social situation of seriously lack of sense of responsibility, the responsibility education should be placed in the first place in college students' education. Only when the college students have a correct sense of responsibility, can they become a new generation who will work hard and have a strong sense of responsibility in their future jobs. At the same time, the current society emphasizes the innovation development, which requires students to possess the ability of innovation. The sense of responsibility is a new power of this ability and can promote the formation and development students' innovation ability fundamentally. The proportion of college students in the future youth generation of China is very high, which means that the dominant position of social life is occupied by such a group. They are closely bound up with the future of the motherland, in other words, the quality of contemporary college students determines the future of our country. Therefore, the improvement of college students' sense of social responsibility is not only related to the growth and success of college students, but also related to the future development of the motherland.

The third one is that colleges and universities should regard the education of the sense of social responsibility as the most important link of the whole moral education. As a qualified citizen, they should learn to undertake the responsibility, enhance the self moral cultivation continuously and pay attention to the cultivation of sense of social responsibility. Only in this way, can they become qualified citizens with responsibility. In our life, we pursue our own ideal life and hope we can get more happiness and satisfaction, but we also should pay attention to the cultivation of the sense of social responsibility. It plays a key role in moral personality, and meanwhile is a key standard to determine whether a person is mature and excellent. It is an important reflection of moral education. If a person has a strong sense of social responsibility, then this person is a moral person. On the contrary, he will be confused about the future and become a man whose mind is always changeable, even seriously, endanger the social security and stability. The ideological and moral education of college students includes patriotism, collectivism and socialism education, which all can be regarded as the problem of cultivating and improving the sense of social responsibility of college students. Through the above analysis, we can roughly understand the importance of the cultivation of the sense of social responsibility for the new generation of college students. It is not only related to the personal development, but also related to the future development of the motherland, so it should arouse great attention from all walks of life.

For many college students, they all think that the university education is mainly to learn all kinds of knowledge, but they ignore an important premise, that is to learn how to be a good person. Only when they have learned how to be a good person in the society, can they have the correct values and life ideals and correctly apply their knowledge to the pursuit of their own ideals. To be a good person and fulfill their rights and obligations is a personal responsibility. Therefore, contemporary college students must put the cultivation of their sense of social responsibility on the key position in the new era. Only in this way, can they become a new generation that can successfully accomplish their mission. From the above overview, we can clearly realize the importance of college students' responsibility education. We must have a full understanding and pay enough attention to the responsibility education, and take the cultivation of the sense of social responsibility of college students as the key part of the whole university education. 


\section{The Current Situation of College Students' Sense of Social Responsibility and Its Main Reason}

Specific Performance. The first one is to pay more attention to personal prospects but belittle social ideals. With the development of our country, the college students who live in a new environment have their own ideals and pursuits. They look forward to cutting a figure soon in the society and doing the great work. They hope that their future is bright and pay more attention to their own development and benefit, but at the same time, there is a serious problem that they ignore the consistency of the individual needs and people's interests and the combination of the personal prospects and country's future.

The second one is to pay more attention to the self-worth but belittle the social value. Since the founding of New China, a tremendous change has taken place. In the current economic environment, many college students have been affected. They have changed their value orientation, and are self-centered. They look forward to cutting a figure soon in the society and doing the great work. They hope that their future is bright, but they seldom take into account the responsibility of themselves for society and country, seriously lack the spirit of collective sacrifice and ignore the integration of self-value and social value.

The third one is to pay more attention to the material benefits but belittle the spiritual pursuit. With the increasing of the economic and cultural openness of our country, the penetration of cultural exchanges becomes more frequent and the contemporary college students are also vulnerable to the wave of western thought, favorable and bad. The bad thoughts have had an effect on the world outlook and life view of the contemporary college students, for example, under the influence of such trend of thought, many college students put the material pursuit in the first place. They think the target of self success is to gain more wealth, higher social status and position. They have no spiritual pursuit.

The Reason of the Current Situation of the Sense of Social Responsibility of College Students. The first one is the social aspect. With the accelerated pace of social development, the market economy is impacting the whole market. The interest first has become a ubiquitous and profound value. And also this idea has had a serious impact on the psychology of contemporary college students. As college students have not yet entered the society and their cognition of society is not comprehensive and rational, they will produce some one-sided extreme ideas. Especially in today's competitive society, college students are stressed about employment, and colleges and universities also put the cultivation of college students' sense of social responsibility aside. In this environment, many students are also lack of the clear understanding of the practices and public service activities, even they participate in it holding the mentality of coping activities. Then such activities will be of no significance.

The second one is the aspect of the family environment. In modern society, the biggest characteristic of college students is that most students are the only children. Under such circumstances, most of them are over indulged by their parents throughout their growth process. At the same time, with the intensification of social competition and the impact of Knowledge economy society, many China family parents spend most of the energy in how to cultivate and improve the the level of cultural knowledge of children but ignore the moral cultivation of children. Thus, many students become egoistic, just know to enjoy their rights but don't know to fulfill their obligations and are seriously lack of the sense of social responsibility.

The third one is the characteristics of college students themselves. College students can be said to be at the same level of culture, but they are on various self consciousness development levels. Through years of efforts, many students finally entered into their favorite colleges, but because of their pride, they can't have a fair and objective understanding of themselves and can't get a clear understanding of their status and role of the society, not to mention the sense of social responsibility and historical mission. Many college students can clearly realize their mission, but it is difficult to internalize this belief, so they can not form their own sense of social responsibility. 


\section{The Path to Increase the Sense of Social Responsibility of Contemporary College Students}

Self-cultivation. The key to strengthening the sense of social responsibility of college students is their self-cultivation. They should first correctly recognize and evaluate themselves through the relevant learning and practice, and then control themselves through their own willpower and belief and also improve the ability of self education. Finally, they should gradually undertake their social responsibility and enhance their sense of social responsibility through the joint efforts of their own, family, school and society.

The Cultivation by Family. The first one is that parents should foster the sense of responsibility of their children towards the family. As parents, they should take the child as a member of the family consciously, let them learn to respect the old and cherish the young and let them care for every member of the family. At the same time, they should also let their children participate in the things management of their family, so as to enhance their consciousness of family responsibility.

The second one is that parents should cultivate the sense of collective responsibility and sense of social responsibility of their children. In life, parents should also consciously let their children participate in collective activities and public benefit activities, so as to enhance their sense of social responsibility and social moral awareness.

The Cultivation in Higher Education. The first one is to enrich the content of ideological education. In the aspect of ideological education, students should first persevere in learning the important thought of Marxism, Mao Zedong thought, Deng Xiaoping theory and "Three Represents", meanwhile, and they should also further study the socialist core value system and establish a correct world outlook and the life outlook on the basis of it. In addition, the study of legal awareness and social moral awareness of college students should be enhanced, and the education and cultivation of students' rights and obligations should be paid highly attention.

The second one is to vigorously publicize traditional virtues. A long history of five thousand years carried numerous fine traditions of the Chinese nation. These are the precious wealth for modern people and also excellent resources of modern education. Therefore, colleges and universities should fully discover and apply these precious wealth in order to serve for the education and cultivation of the sense of social responsibility of modern college students.

The third one is to optimize the mode of education, and use the example role to carry out the education of sense of social responsibility. In the new era, the effect of many traditional education method is not good enough, especially the ideological and political education which takes the infusion teaching as the main method. As for the new generation of college students, colleges should use some proper education methods to cultivate college students' sense of social responsibility, such as elicitation education, model education, etc. It will give full play to the students' dominant position and also easily cultivate students' sense of responsibility.

The fourth one is to pay attention to the intensification of social practice towards the sense of responsibility. If the education of the sense of social responsibility stays in the textbook stage all the time, the effect will be not good enough. So at this time, the social practice should be used well. Colleges and universities should pay attention to the importance of social practice in the cultivation of the sense of social responsibility of college students, enhance the application of social practice and also through some theme activities and conscious activities cultivate students' will and character in order to improve their sense of social responsibility.

The Cultivation in the Society. The first one is that the positive social atmosphere plays a role in promoting the cultivation of college students' sense of responsibility. Society is the environment that all students have to face finally, therefore, it is the best place to cultivate the sense of social responsibility. In such places, the cultivation of college students' sense of responsibility can be promoted directly, therefore, a positive social atmosphere should be created to help college students to feel, study and enhance their own sense of responsibility. Specifically, the form of the enactment and implementation of targeted reward and punishment system, and the entertainment-oriented dissemination and promotion can be used.

The second one is to create a good atmosphere for Internet education and give play to the positive role of the Internet. The Internet is a double-edged sword, so the state should safeguard the 
health of the network space through the construction of the relevant network legislation, and help students to make full use of modern network tools to cultivate the sense of responsibility. In the relevant network education program, some ideological and political education of college students should be carried out consciously, so as to cultivate and enhance the sense of social responsibility of college students through the study and communication of multiple channels, such as the psychological consultation mailbox, BBC, etc.

\section{Conclusion}

It can be said that college students are the backbone of the future society and have a far-reaching impact on the development of future society. Nowadays, the lack of the sense of social responsibility of college students should arouse the attention of all sectors of society. This paper analyzed the reason of lacking the sense of social responsibility of college students and put forward the corresponding measures from multiple angles. We believe that through the effects from each aspect, the sense of social responsibility of college students can be improved roundly and the current situation of the deficiency of the sense of social responsibility of college students can be changed, which will lay the foundation for a better future of the motherland.

\section{References}

[1] X.S.Bi: Colleges and Universities Should Strengthen the Cultivation of College Students' Sense of Social Responsibility[J], MeiTan Higher Education, 2007(4).(In Chinese)

[2] D.L.Zhang: The Characteristics of College Students' Moral Outlook and the Choice of Educational Methods[J], Studies in Ideological Education, 2002, (8).(In Chinese)

[3] D.S.Li: Cultural Desertification and Its Control[J], Academic Exchange, 2001,(3).(In Chinese)

[4] Z.Y.Xie: Conception of Enhancing Actual Effect of Responsibility Education for College Students[J], Educational Theory, 2005(4).(In Chinese)

[5] D.F.Cheng: Reflections on the Responsibility Education of College Students[J], Journal of Ideological \& Theoretical Education, 2006(2).(In Chinese)

[6] Y.L.Wang: The Cultivation of Sense of Social Responsibility of Contemporary College Students[J], Henan Education(College Edition), 2006(8).(In Chinese)

[7] P.Zhou: The Cultivation of Sense of Social Responsibility of Contemporary College Students[J], China Adult Education, 2007(11).(In Chinese)

[8] H.Y.Wang: How to Give Full Play to Ideological and Political Education in the Market Economy[J], Occupational Circle, 2008(9).(In Chinese)

[9] Book Writing Section: Ideological and Moral Cultivation and Legal Basis[M], Higher Education Press,2007.(In Chinese)

[10] J.Xie: Social Responsibility Theory[M], Shanghai Century Publishing Group, 2007.(In Chinese) 